\title{
Rethinking the Improvement of Medieval Cities in the Eastern Europe Through "Bone Causeways"
}

\author{
Liliya V. Yavorskaya* \\ Institute of Archeology RAS \\ Moscow, Russian Federation
}

Received 18.01.2020, received in revised form 18.03.2020, accepted 27.04.2020

\begin{abstract}
Following the methodological scheme initiated in the Laboratory of Natural Sciences, the Institute of Archaeology of the Russian Academy of Sciences, a comparative study of unique phenomenon of medieval urban improvement - animal bones-backed causeways in the central streets - is carried out. Such clusters of bones are the results of archaeological researches in two cities of the Russian north-west area, i.e. Pskov and Novgorod, and in the Golden Horde city of Azak, that is, in completely different natural conditions and cultural contexts.

The study is aimed at identifying mutual and specific features of such clusters, their role in the urban improvement, as well as at obtaining the information about possible causes and conditions of their occurrence, additional data on the economy of these regions in the Middle Ages.

The study demonstrates, that the conditions for the "causeways" formation and functioning in both cases are generally similar. These clusters are marked with high concentrations of the bone remains, their low fragmentation, ordinary taxonomic set, but with depleted quantitative indicators for all economic categories, except for domestic hooved animals. In the Russian cities, the causeways consist of non-meaty parts of chopped cattle heads, while the Golden Horde city of Azak is characterized with the heads and lower parts of the large and small cattle limbs.

The anatomical set clarifies the clusters' nature: in Russian cities they are the waste left from the meat trade, in the Golden Horde - from the leather production. In the studies cities, the bone fillings were used as a sealing material for the central trading areas and streets improvement. The condition for their occurrence is mass production of cattle products, well-established relations between the cities and agricultural district, and high level of urbanization. It is noted that in the Golden Horde these conditions developed in the $14^{\text {th }}$ century, that is, much earlier than in the Russian cities.
\end{abstract}

Keywords: archaeozoology, bone causeway, medieval city, taxonomic set, osteological spectra, domestic hooved animals, anatomical set, meat trade, leather production, improvement, mass production of cattle products, urbanization.

\footnotetext{
(C) Siberian Federal University. All rights reserved

* Corresponding author E-mail address: 1v.yavorskaya@gmail.com ORCID: 0000-0002-5272-7442
} 
The research was completed by the RFBR, project no. 20-09-00310 "Archaeozoological materials as a source for the reconstruction of paleo-economic processes in the forest and steppe zones of Eastern Europe in the XII-XVI centuries".

Research area: archaeology.

Citation: Yavorskaya, L.V. (2020). Rethinking the improvement of medieval cities in the Eastern Europe through “bone causeways". J. Sib. Fed. Univ. Humanit. Soc. Sci., 14(1), 128-136. DOI: 10.17516/1997$1370-0575$.

\section{Introduction}

The problems of improving the urban territory and the household and industrial waste disposal system have been urgent for not the modern sophisticated urban society only - they were efficiently and originally solved in the medieval cities, in the Eastern Europe, indeed.

In the archaeological research of 1930 $50 \mathrm{~s}$ in the medieval cultural stratifications of the Russian north-west cities - Novgorod and Pskov - horizontally extended thick clusters of animal bones, both above and below various wooden structures, were found.

These clusters were not so quickly defined. In the late 1930s A. Strokov and V. Bogussevich, who first faced this phenomenon when conducting Yaroslav's Court digs in Velikiy Novgorod, suggested that the bones might constitute the causeway of the territory of Dvorishchensky Torg (eng. - Trade Mart) (Strokov, Bogusevich, 1939: 14). A.V. Artsikhovskiy, who worked in the same place, at Yaroslav's Court, in 1949 and traced the way of the bone clusters occurrence above and below the wooden structures, argued that the bones were a backing for the wooden paving, and when new structures were laid over the earlier ones, this backing renewed as well (Artsikhovskiy, 1949: 160-161). It was Artsikhovskiy who called such unique clusters "bone causeways".

Another, completely different, interpretation was proposed by G.P. Grozdilov, who came across very similar bone collections, when exploring the territory of Noviy Torg in Pskov. He suggested considering such clusters as something of the meat trade remains (Grozdilov, 1962). Further archaeological and archaeozoological findings of $2008-09$ and in 2011 in these sites allowed clarifying the strati- graphic context, dates, species composition of the bones and anatomical sample of the largest specie, as well as the carving features (Yavorskaya, 2013; Yavorskaya, 2013a). There was a multidirectional research: it was important to understand not only the purpose of using such amounts of bones on the trading courts in the cities, but also find the places of their production, accumulation, and the way of how they entered these clusters. Finally, both interpreters were right: a unique anatomical set, consisting of "non-meaty" parts of cow heads, was a result of the meat trade, but it was used precisely as a concrete backing under the wooden structures to protect them from rotting in the waterlogged soils, i.e. to improve the public area.

In the early $21^{\text {st }}$ century, such "bone causeways" were found in another medieval city, in a completely different cultural and natural environment: in the $14^{\text {th }}$ century strata of the Golden Horde city, Azak, on the Lower Don (today the city of Azov, Rostov Oblast'). A dry steppe climate protected the wooden structures from waterlogging there. The archaeozoological research has shown that the causeway contains the bone remains of mostly two domestic hooved animals - large and small cattle, and the anatomical set is full of the heads and lower extremities - the most important parts - that is, the remains of animal killing for skinning (Yavorskaya, Maslovskiy, 2018: 372-373). Thus, the concentration of bone clusters found in the Golden Horde city can be explained differently than in the old Russian ones, although with their similar use.

\section{Concept of the study}

The research on the animal bones at archaeological sites involves the processing of 
two-types-information source. On the one hand, the bones are of biological "origin," on the other hand, they fill the cultural strata, being the traces of human life and activity. This study is basically grounded on the perception of animal bone remains as a source of mainly archaeological and historical information (Antipina, 2016: 100).

\section{Problem statement}

The phenomenon of "bone causeways" was found in cities of very much different natural and climatic conditions. They occurred in at different times, which separated them by nearly two centuries.

This research aims conducting a comparative analysis of unique landscaping objects, to identify possible causes that launched their occurrence, general and specific features of the clusters in the medieval cities belonging to various natural and climatic zones. The study is quite reasonably judged by the criteria following which the comparison is made, i.e. archaeological, archaeozoological and historical. The first set of criteria clarifies the conditions of occurrence, length of the bone causeways in certain archaeological context; the stratigraphic and planigraphic distribution of the bones in the "causeways" and the strata thickness are identified. Revealing the reasons why certain anatomical set of specific animals was included into the causeways is another task, which leans on archaeozoological criteria. These include the assessments of taxonomic and species composition, identification of the anatomical set of the most frequent species, traces and nature of carving and other marks of artificial interference, natural integrity and artificial fragmentation of the bones. The third block of objectives is to shed the light on the places and conditions of the causeway constructions in the medieval city, to clarify historical, landscape and climatic and economic-political premises for their formation.

The main objects of the study and comparative analysis are the samples of the bone remains found in the city causeways and obtained from the archaeological research in the medieval cultural strata of two cities - Pskov and Azov, where a complete archaeozoological research of such bone remains was carried out.

\section{Research methods}

The archaeozoological research is based on the techniques developed in the laboratory of natural science methods in archaeology of the Institute of Archaeology, Russian Academy of Science (Antipina, 2004). Apart from traditional methods of taxonomic identifications in archaeozoological studies, recording the age and, if possible, the sex of animals, measuring whole bones (see: Antipina, 2004; Antipina, 2009; Antipina, Morales, 2006), this methodological scheme uses the approaches which are quite rare in our country, e.g. recording the natural integrity of the bone fragments, the degree of fragmentation, traces of artificial interference, such as: fire and heat traces, chopping and knife blade cuts, craft processing, predators or rodents' bites. Moreover, the results also concern the measurements on pathologies and other animals' characteristics (Antipina, 2016: 105).

For the concerned bone "causeways", all the above measurements have been obtained, and the most distinctive indicators are:

- the extent of the fragments' natural integrity (five-point scale, 1 is the lowest rating and unsatisfactory integrity);

- mammalian bones fragmentation index $(\mathrm{FI}=$ number of fragments filling a standard unit of $1 \mathrm{dm}^{2}$ (Antipina, 2004);

- traces of artificial interference on the bone fragments;

- taxonomic structure of osteological clusters, the share of domestic hooved animals in the osteological set;

- anatomical structure of the dominant domestic hooved animals.

All the samples involved in the study have been analysed according to a single methodological research scheme, thus, has made it possible to compare them relying on the archaeological, archaeozoological and historical criteria mentioned above.

\section{Discussion}

The main features of the bone causeways in the medieval cities can be explained and dis- 
cussed through the main results of archaeological and archaeozoological findings following the objectives stated previously.

\section{Lugsky-II-2011 site (Pskov)}

A massive filling with homogeneous bone remains was found in all the sites in the upper part of the medieval strata. The total body of the studied collection is 31060 fragments. The natural integrity of the bone remains is good 4 points out of 5 , traces of artificial impacts on the bone fragments are clear. The archaeological research, a complete sample of all the findings, including the bone remains, and levelling of the land layer were followed by the fact that the bone backing, in fact, evened out this part of the city. The deepest parts of the site were marked with the most massive strata. The top five medieval strata in A-section were densely filled with the bone remains, the number of bones in these samples was from 2000 to 9000 fragments to one layer. In section 3, where the soil marks were higher, the bone clusters occupied only $3-4$ upper layers, with the amount on each layer of almost $1000-2000$ fragments. In the highest areas of $\Omega$ and $M$, the bone strata were only $1-2$ layers, with nearly 100 fragments of bone remains in each of them. There were two most possible variants of artificial interference found on these fragments. Firstly, the traces of an oriented standard butchering of an animal, secondly, there are the traces of ash discharges. Importantly, in this case, we managed to distinguish the traces of discharges of already dead combustion products - ash, from the ones of direct fire, since there were grey gold spots identified on one side of the bone, and no such traces on the other side (Yavorskaya, 2013: 43-46).

The bones in the "causeways" were slightly fragmented, i.e. $10-18$ fragments per $1 \mathrm{dm}^{2}$. The biggest part - $96-98 \%$ of all bones from different sites - was largely definable fragments. The taxonomic set of bone remains is common for the medieval Russian city, but the proportion of bird and fish remains, wild mammals and domestic predators is unusually low, making up only tenths or even hundredths of a percent in each sample. Normally, in the Russian cities, the amount of such remains is much more than 1\% (Yavorskaya, 2017: 217). 96\% of the bone remains belong to domestic hooved cattle. In the medieval Russian city, the cattle bones always dominate in the osteological context, but their part, indeed, does not exceed 70\% (Antipina, 2005: 183). The next place in the hierarchy of species is conventionally taken by pigs, horses and small cattle. In our sample of the bone causeways, the amount of all other domestic species is little: $2.5 \%$ is for the small cattle, the other species do not even reach $1 \%$ (Yavorskaya, 2013a: 48).

The anatomical set of the most numerous species is very indicative - over $90 \%$ of all the large cattle bones are the head remains, i.e. frontal bones and teeth of the upper and lower jaws. The cutting of these parts is standard, i.e. the anatomical set consists only of those parts of the animal head which almost do not have meat or even gelatin. Such remains could be the result of the meat trade, since they are unsellable parts of the corpse. Thus, the remains and their storage could be in public catering, i.e. in taverns or hasheries, where stock soups were cooked (Yavorskaya, 2013). Thus, the remains were disinfected and no longer posed a threat to the sanitary state of the city. Another argument supporting this version is the traces of ash on the bones - the ash from the tavern ovens was removed in the same places. Such specific anatomical set was also recorded for the cultural strata of the $16^{\text {th }}$ century in Yaroslav's Court in Novgorod (Yavorskaya, 2013).

The bone clusters of cow heads fragments at Lugsky-II site filled the low wet lands of Noviy Torg territory in Pskov. The bone backing was covered with the wooden structures - a wide flooring-causeway, as well as the lower crowns of wooden small shops. Apparently, these backings were also used at the Court in Novgorod for the same purposes (Artsikhovskiy, 1949). In both cities of the Russian northwest, such backfill was designed precisely to protect the wooden structures from rotting in the waterlogged soil.

Let us also note the parallels in the bone causeways appearance for two cities: in both cases, these specific bone fillings were found on the main trading area and dated back to the $16^{\text {th }}$ century. 
Such coincidence cannot be accidental, since the history of the "causeways" occurrence is similar. IN the early $16^{\text {th }}$ century, after the republics of Novgorod and Pskov were joined to the Moscow State, in order to make the trade aristocracy completely obey to the new authorities, the central shopping areas of the cities were rebuilt. In Pskov, a new place was given to the main city trade mart outside the walls of the Medium City, which turned out to be low-lying and rather marshy, but was levelled and drained with the massive bone backings. In Novgorod, Torg remained its position in the Court, but was completely rebuilt, using a specific backfill from the fragments of cow heads.

\section{Petrovskiy Bulvar, 7-2013, site 2 (Azov)}

The remains of the main city street filled with the animal bones had to be explored by the Azov archaeologists more than once in different times. For the first time, a specific "causeway" was noted in $2000-2003$ through the sites at Tolstogo ulitsa, 41. Another detailed archaeological investigation was conducted for the materials of \#№2 site of at 7 Petrovskiy Bulvar, in 2013, where the causeway found its continuation (Yavorskaya, Maslovskiy, 2018: 364).

At the site at Tolstogo ulitsa, 41, an almost 8-m wide causeway was found. The street was built on a specially created $0.2 \mathrm{~m}$ deep hollow. The surface of the soil under was densely packed tiled structure, with a layer of dark brown loam on the top, oversaturated with findings. The pavement consisted of multiple fillings on the loamy surface with plenty of solid debris, including animal bones (Yavorskaya, Maslovskiy, 2018: 359).

The amount of archaeozoological collection of large excavation sites on Petrovskiy Bulvar was 24,875 bone fragments. Their natural integrity was called satisfactory and good, i.e. $3-4$ points out of 5. There partially were the traces of a chemical substance, which worsens the bones' integrity and increases the natural tafonomic fragmentation. 3134 bone fragments were found right on the causeway. The bone fragmentation index of this sample is 22-23 fragments per $1 \mathrm{dm}^{2}$. Most of the bone remains were marked with visible traces of artificial interference, resembling some of a kitchen crushing. The strata's density with the bone remains can be approximately estimated as 100 fragments per $1 \mathrm{~m}^{2}$, while in ordinary household clusters the number of bones the same site area does not exceed 20 fragments (Yavorskaya, Maslovskiy, 2018: 371).

The taxonomic structure contains ordinary remains of domestic and wild mammals, birds and fish, however, quantitative indicators for all the groups of bone remains are odd. Thus, the share of bird and fish remains is $0.1 \%$ of the total amount of bones, the ones of domestic predators - only $0.5 \%$ and about $3 \%$ are undetectable mammalian remains. The remains of wild animals are not found. As in the old Russian bone causeways, the collection is clearly definable $-96 \%$, although the bones' integrity is worse and their fragmentation is higher (Yavorskaya, Maslovskiy, 2018: 366-367). Just like in the Russian cities, in the Azak's causeway the taxonomic set of bone remains has been depleted, as well.

The other remains from the "causeway" have been classified into three types of domestic hooved animals: large and small cattle, and horses. As for the osteological context the small cattle dominate $-62.7 \%$, the large cattle $36.5 \%$, the share of horse remains is extremely low - less than 1\% (Yavorskaya, Maslovskiy, 2018: 368). No pig bones were found on Azak's causeway. Such a hierarchy of species is also common for the household clusters of bone remains in Azak.

The anatomical set of both types of cattle appeared to be out of the ordinary. Thus, for the large cattle, there is high density the heads and distal extremities remains - metapodia and phalanges (Yavorskaya, Maslovskiy, 2018: 369, Table 3), while the number of other skeleton elements is normal, following the conventional standard set of one cattle corpse. Almost the same anatomical set was recorded for the remains of small cattle, but the number of phalanges is small, by contrast with scapula. Obviously, the causeway filling was made up of certain cattle bones left by the massive butchering. That brings us to say, that the waste from the primary carvings 
when skinning was deliberately put into the causeway. The bones were marked with some traces of chemical substance, i.e. the remains suffered processing before filling the causeway. This treatment, to some extent, worsened the integrity and increased fragmentation of the bones, comparing to their normal everyday clusters, and these indicators are lower than in the paved areas of the Russian cities. As we can see, the species and anatomical set in Azak's causeway is somewhat different from the ones in the Russian cities. The main difference is explained by the origin of the remains: as for the Russian cities, they were wastes from the meat trade, and for the Golden Horde city - the ones left from the leathers production.

The history of the bone causeways formation in the Golden Horde city is the following: the central street of Azak was formed on the cusp of $13^{\text {th }}$ and $14^{\text {th }}$ centuries and served for the most of $14^{\text {th }}$ century (Yavorskaya, Maslovskiy, 2018: 359). The use of bone filling for its backfilling, apparently, began no longer than in $14^{\text {th }}$ century. A plenty of coins were found there, close to various craft industries, including bone-cutting and leather ones, as well as trading shops. It was the busiest central street of the city, its heart and one of the main Trades. Of course, in the rainy period this street would sink in the liquid and sticky mud of the loamy soils lacking its special arrangement and strengthening. Such smart use of the bone remains left by the leather industry solved two problems at a time: it utilized organic waste and concreted the central city street. This happened in much the same way that the waste from the meat trade was disposed of in causeways, thereby developing the central streets and squares of the north-western Russian cities of the $16^{\text {th }}$ century.

The study of the causeway bone remains reveals several important facets of Azak and the Lower Don's history and economy in the Golden Horde period. It shows that the city actively traded with the steppe, receiving there and in the nearest districts animal raw materials for leather and bone carving industries. The medieval documents states that in the $40 \mathrm{~s}$ of the $14^{\text {th }}$ century the commercial duty (rus. - kommerkiy) for the export of raw animal skins increased (Bocharov, Maslovskiy, 2015: 7 - 8) and, apparently, mass processing was launched, the waste of which are observed inside its central causeway.

\section{Conclusion}

The comparative analysis of the bone causeways in the medieval cities of Eastern Europe has showed that they are similar in most of the conditions for their formation and functioning.

Both cases are featured with higher density of the bone remains than any ordinary cluster. The fragmentation of the bones laid in the causeways is usually lower than in simple stores, and their integrity is possible due to specific factors. Thus, better integrity is noted in the Russian cities of the north-west with a moistened cultural layer, and the processing of bone fragments before laying in the causeways here was carried out using cooking and ash backing, which strengthened the bone tissue. Before laying in the causeway of Azak, the bone remains were treated with a chemical substance, which destroyed the bone tissue, reduced the natural integrity and increased tafonomic fragmentation.

The taxonomic set of remains coinsides with the traditional set for these cities. However, the quantitative indicators for all "domestic" groups of animal bones, except for the domestic "meat" hooved animals, are depleted in both cases. The bone of domestic hooved animals, on the contrary, have exceeded indicators as to their normal household accumulation. The species set of domestic meat hooved animals found in these causeways depends on the natural conditions of the area and the cultural traditions of specific communities. For the Russian cities located in the forest zone, the main filling is the large cattle's remains - an animal brought up by the population of this territory. The causeways of the southern city of Golden Horde, close to the nomadic steppe, the bones of two main types, large and small cattle, which were bred both in city and drove from the nomadic steppe, are found. The causeway in the Golden Horde was quite often filled with the remains of small cattle. 
The archaeozoological analysis has identified two different anatomical sets of bone remains in the clusters. Regarding the Russian cities, these are the remains of non-meaty parts of cow heads, while in the Golden Horde city, the causeways are backed with the heads and distal parts of the cattle's limbs. The findings on anatomical features of numerous species clarify the origin of the bone remains in clusters: as for the Russian cities, they are the wastes from the meat trade, while in the Golden Horde, they are something left after leather production processes.

In both cases, numerous bone wastes acquired new functional aim within the urban space - they were used as sealing material for the street paving, that is, for the city develop- ment. All causeways under our consideration are in socially important areas of the cities, linked to trade. Apparently, highly intensive use of these urban facilities required specific care.

In both objects, the clusters of so specially selected bone remains were determined by mass production of the cattle products. The second and third conditions should be the presence of well-established economic relations between the cities and their districts that supply such products, as well as a high level of urbanization, care for significant objects in the city territory. The chronology of the causeways constructed of the animal bones shows that the emergence of such industries and relations were much earlier in the Golden Horde, than in the north-west Russian cities.

\section{References}

Antipina, E.E. (2004). Arheozoologicheskie materialy [Archeozoological Materials]. In Kargaly. III. Selishche Gorniy: arkheologicheskie materialy, tekhnologiya gorno-metallurgicheskogo proizvodstva, arkheobiologicheskie issledovaniya [Kargaly. III. Gorny Village: Archaeological Materials, Mining and Metallurgical Production Technology, Archaeobiological Research]. Moscow, Yazyki slavyanskoi kul'tury.

Antipina, E.E. (2005). Myasnye produkty v srednevekovom gorode - proizvodstvo ili potreblenie? [Meat Products in a Medieval City - Production or Consumption?]. In Arkheologiya i estestvennonauchnye metody [Archeology and science method]. Moscow, Yazyki slavyanskoi kul'tury.

Antipina, E.E. (2009). Rostislavl'skoe gorodishche dyakovskogo vremeni: arkheozoologicheskie materialy iz raskopok 2002-2006 godov [Rostislavl Ancient Settlement of the Dyakovo Era: Archaeological Materials from Excavations of 2002 - 2006]. In Analiticheskie issledovaniya laboratorii estestvennonauchnyh metodov [Analytical Research Laboratory of Natural Sciences Methods], 1, 146 - 171.

Antipina, E.E. (2016). Sovremennaya arkheozoologiya: zadachi i metody issledovaniya [Modern Archaeozoology: Tasks and Research Methods]. In Mezhdisciplinarnaya integratsiya v arkheologii (po materialam lektsiy dlya aspirantov i molodykh uchenykh) [Interdisciplinary Integration in Archeology (based on lecture materials for graduate students and young scientists)]. Moscow, IA RAN.

Antipina, E.E., Morales, A. (2006). Arkheozoologicheskiy podhod k izucheniyu ustroistva obshchestva: Kosti zhivotnyh iz dvuh poseleniy gornyakov i metallurgov vostochnoy i zapadnoy okrain Evropy [Archeozoological Approach to the Study of Society: Bones of Animals from Two Settlements of Miners and Metallurgists in the Eastern and Western Outskirts of Europe]. In Arheologiya, etnologiya i antropologiya Evrazii [Archeology, Ethnology and Anthropology of Eurasia], 3 (27), 67 - 81.

Artsikhovskiy, A.V. (1949). Raskopki vostochnoy chasti Dvorishcha v Novgorode [Excavations of the Eastern Part of the Courtyard in Novgorod]. In Materialy i issledovaniya po arkheologii SSSR [Materials and Research on Archeology of the USSR], 11, 152 - 176.

Bocharov, S.G., Maslovskiy, A.N. (2015). Pis'mennye istochniki ob ital'yanskoy torgovle kozhey v Severnom Prichernomor'e i dannye arkheologii [Written Sources about the Italian Leather Trade in the Northern Black Sea Region and Archeology Data]. In Uchenye zapiski Kazanskogo universiteta [Scientific Papers of Kazan University. Humanities], 157 (3), 7 - 11.

Grozdilov, G.P. (1962). Raskopki drevnego Pskova [Excavations of the Ancient Pskov]. In Arkheologicheskiy sbornik Gosudarstvennogo Ermitazha [Archaeological Collection of the State Hermitage Museum. Slavic Antiquities], 4, 7 - 76. 
Strokov, A., Bogusevich, V. (1939). Arkheologicheskoe issledovanie Novgoroda [Archaeological Research of Novgorod]. Novgorod.

Yavorskaya, L.V. (2013). "Kostnye vymostki" v drevnerusskih gorodakh: "anatomiya" odnoy arheologicheskoy zagadki ["Bone pavements" in Ancient Russian towns: "anatomy" of one archaeological riddle]. In Zoologicheskiy zhurnal [Journal of Zoology], 92 (9), 1179 - 1189

Yavorskaya, L.V. (2013a). Torgovlya myasom ili vymostki iz kostey? Arkheozoologicheskie issledovaniya raskopa Luzhskij-II v Pskove [Meat Trading or Bone Paving? Archeozoological Studies of the Luzjskij-II Excavation Site in Pskov]. In Arheologiya i istoriya Pskova i Pskovskoj zemli [Archeology and History of Pskov and the Pskov Land], 29 (59), 42 - 55

Yavorskaya, L.V. (2017). Arkheozoologicheskie materialy Kremlevskogo raskopa-I [Archeozoological Materials of the Kremlin Excavation-I]. In Novgorodskiy detinets i Vladychnyj dvor v XI-XV vv. [Novgorod's Inner City and Vladychny Dvor in the $11-15^{\text {th }}$ centuries]. Saint-Petersburg, Dmitriy Bulanin.

Yavorskaya, L.V., Maslovskiy, A.N. (2018). Nakhodki skopleniy kostey zhivotnykh v zolotoordynskom Azake: vidovoy sostav, anatomicheskiy nabor, topografiya [The Findings of Animal Bones Clusters in the Golden Horde City of Azak: Species Composition, Anatomical Set, Topography]. In Istoriko-arkheologicheskie issledovaniya v Azove i na Nizhnem Donu v 2014-15 gg. [Historical and Archaeological Research in Azov and the Lower Don in 2014 - 15], 30, 358 - 378. 


\title{
Вопросы благоустройства средневековых городов Восточной Европы на примере «костных вымосток»
}

\author{
Л.В.Яворская \\ Институт археологии РАН \\ Российская Федераџия, Москва
}

\begin{abstract}
Аннотация. По методической схеме, разработанной в лаборатории естественнонаучных методов Института археологии РАН, проведено сравнительное исследование необычного феномена средневекового городского благоустройства — вымосток из костей животных, служащих заполнением центральных улиц. Такие скопления костей обнаружены при археологических исследованиях в двух городах русского Северо-Запада, Пскове и Новгороде, и в золотоордынском городе Азак, то есть в совершенно разных природных условиях и культурных контекстах.

Цели исследования - выявить общие и специфические черты подобных накоплений костей, их роль в городском благоустройстве, получить сведения о возможных причинах и условиях их возникновения, дополнительные данные об экономике исследуемых регионов в эпоху Средневековья.

Исследованием установлено, что в основных чертах условия образования и функционирования «вымосток» в изучаемых городах сходны. В скоплениях зафиксированы высокая концентрация костных остатков, невысокая их раздробленность, обычный таксономический набор, но обедненные количественные показатели для остатков животных всех хозяйственных категорий, за исключением домашних копытных. В русских городах вымостки состоят из немясных частей разделанных голов крупного рогатого скота, а в золотоордынском Азаке в них зафиксированы остатки голов и нижних частей конечностей крупного и мелкого рогатого скота.

Установленный анатомический набор прояснил происхождение скоплений: в русских городах они являются отходами мясной торговли, в золотоордынском - отходами кожевенных производств. Костные подсыпки использовались как уплотняющий материал для благоустройства центральных торговых площадей и улиц изучаемых городов. Условием возникновения подобных накоплений служит наличие в государстве массового производства скотоводческой продукции, отлаженных связей городов с сельскохозяйственной округой и высокий уровень урбанизации. Установлено, что в Золотой Орде указанные условия сложились в XIV в., то есть много раньше, чем в русских городах.
\end{abstract}

Ключевые слова: археозоология, костные вымостки, средневековый город, таксономический состав, остеологические спектры, домашние копытные, анатомический набор, мясная торговля, кожевенное производство, благоустройство, массовое производство скотоводческой продукции, урбанизация.

Исследование подготовлено при поддержке РФФИ, проект № 20-09-00310 «Археозоологические материалы как источник для реконструкции палеоэкономических процессов в лесной и степной зонах Восточной Европы в XII-XVI вв.»

Научная специальность: 07.00.00 - исторические науки и археология. 